\title{
Put on the Wig, It's Time to Ball: Experiences of a Collegiate Men's Basketball Fan Group
}

\author{
Allison Musser and Jon Welty Peachey \\ University of Illinois at Urbana-Champaign
}

\begin{abstract}
The purpose of this study is to explore the experiences of a collegiate men's basketball fan group. Little research has been undertaken exploring student fan groups, especially using ethnographic methods. The primary researcher attended two men's home basketball games at the University of Illinois at Urbana-Champaign, home of the student fan group, Orange Krush. The researcher also interviewed eleven Orange Krush members about their motivations and experiences in the group. The findings include a new benefit not previously found in the literature: Insider Access. An additional apparent theme was the importance of sport rituals, and the perception by the students that these rituals impact the outcome of the game. Finally, students indicated how the group improved their sense of community and diversity on campus. Implications of this research include sport management professionals emphasizing the importance of fan attendance on game success and ensuring fans feel they are closely connected to the teams so that they feel like insiders, which builds the emotional connection between fan and team.
\end{abstract}

Keywords: fan groups, sense of community, sport rituals

Hirt, Zillmann, Erickson, \& Kennedy (1992) defined fandom as “an affiliation in which a great deal of emotional significance and value are derived from a group membership" (p. 725). This emotional attachment to a sports team often leads to a level of dedication in some of the most trying conditions. Most would consider standing outside an arena for hours on a central Illinois night in January an irrational behavior; yet, Orange Krush members do this on a regular basis to ensure they get the best seats to watch the University of Illinois Fighting Illini men's basketball team compete. These student fans, similar to many other students in university fan groups across the country, often dress up in outlandish outfits, paint their faces, and scream until their throats ache. Thus, the connection with college student groups may have meaning for the members in many ways.

As Melnick (1993) points out, with increased individualization, industrialization, and mobility in American society, sport has become an important place for

The authors are with the Dept. of Recreation, Sport, and Tourism, University of Illinois, Champaign, IL. Address author correspondence to Allison Musser at amusser3@illinois.edu. 
entertainment and socialization. This is evidenced during the National Collegiate Athletic Association (NCAA) men's basketball tournament, where the 2015 television ratings were the highest ever for each day of the tournament (Brown, 2015), averaging 11.3 million total viewers (NCAA, 2015), indicating the popularity and significance of this sport among fans. In addition, CBS and Turner, the two networks which broadcast every game, took in more than $\$ 1$ billion in advertising revenue in 2012, making March Madness, not the Super Bowl, the most lucrative TV sports event in terms of ad revenue (Dubner, 2013). The impact of collegiate men's basketball is not just a financial boon to advertisers. For instance, Pope and Pope (2014) found that schools coming off a successful season in either football or men's basketball receive $10 \%$ more SAT scores, indicating that more students intend to apply to the school.

As highlighted above, given the significance and importance of intercollegiate athletics in the economic and social fabric of the U.S., it is important to consider the role of student fan groups within this landscape. Since college is a key period in which students make friendships and connections which will last their entire lives, college sport can be a vital area in which students socialize, making the study of college sport fan groups and their social experiences especially valuable. While previous research explores motivations of sports fans (Funk, Ridinger, \& Moorman, 2003; Milne \& McDonald, 1999; Trail \& James, 2001; Wann, 1995), current literature does not explore student fan groups and the experiences of the participants. Because group affiliation is a primary motivation for sport consumption (Funk, Ridinger, \& Moorman, 2004; Milne \& McDonald, 1999; Trail \& James, 2001; Wann, 1995), it is important to explore how benefits of fan participation in a group may be different from benefits experienced by sport fans in general. Hence, the overarching purpose of this study was to explore the experiences of a collegiate men's basketball fan group.

To focus this study, the researchers explored benefits for participation in the group, using research on motivation for and benefits of sport consumption to guide the research question regarding benefits of participating in a student fan group. An important and visible part of the experience of a collegiate fan group are the rituals that they undertake (Chun, Gentry, \& McGinnis, 2005), so information on sport rituals and sport fan rituals was used to further explore the meaning of ritual in a sport fan group. As part of the focus on rituals, the researchers also explored whether the group perceives that they impact the outcome of the game, since rituals (e.g., cheers, chants) could be a key component in any possible real or perceived impact. Finally, because community within the fan group could be another critical part of the fan group experience, literature on sense of community in sport guided the research question examining sense of community in a collegiate fan group.

\section{Literature Review and Conceptual Framework}

Next, we present our conceptual framework, drawn from literature on benefits of sport consumption, rituals, and the nature of home court advantage to undergird the research questions regarding perception of game impact; and the literature on sense of community to focus the fourth research question on the development of sense of community in a student fan group. 


\section{Benefits of and Motivations for Sport Consumption}

Related to sport fan motivations are benefits of sport team identification. Research in this area has shown several psychological and sociological benefits for sports fans. Much of the research has centered on benefits that occur due to membership in a group and identification with others. As Cialdini et al. (1976) found, fans may use sport team identification to enhance self-esteem through BIRG (Basking in Reflected Glory) or CORF (Cutting off Reflected Failure). For example, they found that fans are more likely to wear team colors after a team victory than after a defeat, showing that fans desire to boost their self-esteem by associating with a successful team. Following this line of research, Branscombe and Wann (1991) found that identification with a sports team increases self-esteem and reduces likelihood of depression. Further, the researchers found that identification with a sports team was positively correlated with a positive outlook on life, as defined by factors including happiness, contentment, and satisfaction with life, and negatively correlated with negative affect, such as alienation and hopelessness.

In addition to exploring the benefits received from being a sport fan, it is also critical to explore benefits received from being in a sport fan group. Previous research has shown the importance of group identification to identity (Tajfel \& Turner, 1986; Tajfel, 1981; Turner, Hogg, Oakes, Reicher, \& Wetherell, 1987). In addition, research has also shown the importance of connection to other people in relation to a specific brand (Heere et al., 2011; Muniz \& O'Guinn, 2001; Murrell \& Dietz-Uhler, 1992; Wann, 2006); thus, studying benefits of being part of a fan group, not just being a fan, is an important area requiring further inquiry, as these benefits could be different from those derived from being a sport fan in general.

One possible benefit to sport fan group participation is more opportunity for Insider Access. While this term is not used in the sport fan literature, the idea can be found in other applications. For example, studies in television fan interaction indicate that participation and "behind the scenes" views are helpful in building loyalty among viewers (Andrejevic, 2008; Baym, 1999). In addition, sport marketing research has shown the importance of relationship building through interaction with fans (Williams \& Chinn, 2010) and enhanced identification through direct experience and knowledge of players (Lock, Taylor, Funk, \& Darcy, 2012). Giving tours of stadiums also can enhance this feeling by giving authentic backstage access (Gammon \& Fear, 2005).

While these benefits are important, it is helpful to examine them in relation to motivation, as the benefits an individual derives from identifying with a sport team are related to why that person choses to identify with a team in the first place. Motivation to identify with a sport team is driven by a need that an individual wants to fulfill or a benefit one thinks he or she will receive (Funk, Filo, Beaton, \& Pritchard, 2009; Kim \& Trail, 2010), so it is important to consider both benefits and motivations together. Research on sport consumption and sport fanship motivation has generally focused on a few recurring motivations: escape, eustress, self-esteem, entertainment, economic, group affiliation, aesthetic, and family, with group affiliation and entertainment being the most important (Wann, 1995). Several models have been created to measure sport fan or sport spectator motivation in addition to Wann's typology above. Milne and McDonald (1999) developed the Motivations of the Sport Consumer Scale, which includes 12 constructs, many of 
which were similar to Wann's, but included risk-taking, aggression, competition, and skill mastery. Stemming from this work, Trail and James (2001) developed the Motivation Scale for Sport Consumption, which combined the previous researchers' motivations for a total of nine motivations, including physical attractiveness of athletes, achievement, aesthetics, eustress, escape, family, social interaction, physical skill of athletes, and acquisition of knowledge. In addition, Funk et al. (2009) developed a typology based on previous research which includes 10 items, which assess five main features of sport event attendance: socialization, performance, excitement, esteem, and diversion. The researchers found that excitement, esteem, and performance were the most important motivations for sport fans to attend a sporting event. Collectively, literature in this area has clearly shown that though the nomenclature may be different, there have been generally consistent results in understanding fan motivation often includes factors such as entertainment, escape, socialization and performance. However, research has also shown that within the 10-12 most commonly reported motivations, there is quite a bit of variability with individual fans.

While there is salient research on benefits of sport fan consumption, there is a gap in the literature regarding benefits of participation in a sport fan group. Because group affiliation is a well-established motivation for sport fan consumption (Funk, Ridinger, \& Moorman, 2004; Milne \& McDonald, 1999; Trail \& James, 2001; Wann, 1995), it is possible that the benefits of being in a sport fan group, rather than for just being a fan, would be different. Based on this gap, the following research question was formulated:

Research Question 1: What are the benefits of attending collegiate men's basketball games as part of a student fan group?

\section{Rituals}

Rituals embody an important way for people to connect to a cultural identity, express membership in the group, and are varied based on individual culture (Chun et al., 2005; Eastman \& Riggs, 1994; Guttmann, 1978; Rook, 1985). Because rituals are unique to the group that honors them (Cottingham, 2012), it is critical to explore rituals in a variety of contexts, including sport fan groups. In addition, because rituals are important to group cohesion and identification (Guttmann, 1978), it is important to explore fan group rituals, not just fan rituals. Fan group rituals may be experienced differently because the actions may be less voluntary due to the expectation of group participation. It is also possible that the rituals in a college sport fan group are created by the leaders of the group, rather than at the grass roots level.

Examples of sport rituals and superstitions range from the entertaining to the truly bizarre. Athlete rituals have included special apparel, such as "lucky" socks, in-game grooming, such as trimming fingernails or brushing teeth, and purposeful nongrooming, such as refusing to shave during the playoffs. Sports fans also engage in many different kinds of sports rituals, including wearing a special outfit, watching a game from a special location, painting one's face in team colors, or enjoying a special meal or beverage. Fans may also engage in cheers or chants as a group in a show of unity against the opponent or gather together after the game to debrief regarding the highs and lows of the game just attended or observed (Chun et al., 2005; Cottingham, 2012; Eastman \& Riggs, 1994). 
Research on ritual at the societal level is plentiful, and additionally, research has focused on sport as ritual in a variety of settings including professional baseball (Holt, 1992), karate (Donohue, 1993), and the Ironman Triathlon (Granskog, 1993). In addition, Scholes (2005) examined the ritualistic sacrifice of an infamous baseball by Chicago Cubs fans and a Chicago restaurant owner. Previous research on sport fan rituals has shown that rituals can enhance attendance, satisfaction of attendance, merchandise purchasing, can create connections between fans and teams, signal membership in the group, and provide empowerment by involving the fan in the event (Eastman \& Riggs, 1994; McDonald \& Karg, 2014). One area of focus for sport fan rituals is pregame tailgating. Research has shown several motivations for participating in tailgating such as escape from everyday stresses, social interaction, involvement, intertemporal sentiment, and identity (Drenten, Peters, Leigh, \& Hollenbeck, 2009; James, Breezeel, \& Ross, 2001). Interaction Ritual Theory (Collins, 2004) has also been used to examine sport rituals, with research in this area showing that sport stadia can contribute to the importance of ritual building for fans, and that emotional connection can extend past the boundaries of the stadium (Cottingham, 2012; Gordon, 2013). An additional area that has contributed to the knowledge regarding sport fan rituals is the idea of brand community, introduced by Muniz \& O'Guinn (2001). A brand community is a group formed based on allegiance to a specific brand. Brand communities are marked by shared consciousness, rituals and traditions, and moral responsibility. In the case of a sport fan group, the fans are bound together by their allegiance both to each other and their team. The rituals they share are a key component to maintaining the community.

Due to the lack of literature on college sport fan group ritual, the current study explored the following question and subquestion:

Research Question 2: To what extent does a collegiate men's basketball student fan group participate in sports rituals?

Research Question 2a: What are the meanings of ritualistic behaviors in a collegiate men's basketball student fan group?

\section{Perception of Game Impact}

We also examined if members of a student fan group perceived that they influenced the outcome of the contest, perhaps through engagement in rituals as described above. The conventional wisdom is that sports teams generally play better at home than on the road, resulting in the phrase "home field advantage." There is research on home field advantage, but due to the complexity of factors involved, the results have been mixed. Courneya and Carron (1992) developed a conceptual framework in an attempt to operationalize the idea of home field advantage, encompassing five factors: game location, game location factors, critical psychological states, critical behavioral states, and performance outcomes. In their framework, the authors identified game location as simply whether the game is at the home arena. Game location factors are crowd, learning, travel, and rules. These factors then affect the competitors, coaches, and officials, both psychologically and behaviorally, which in turn affect the outcome of the game. While this framework has been used in a variety of scenarios to evaluate many of these factors, this discussion will be limited to research regarding the crowd factors, in line with the purpose of the current study. 
Crowd effects can include many different components, such as size, density, noise, and antisocial behaviors. The effects seem to vary based on sport. For example, crowd size and crowd density did not have an effect in English soccer (Dowie, 1982; Pollard, 1986), but crowd density had a positive effect in American Major League Baseball (MLB) (Schwartz \& Barsky, 1977). Crowd behavior has also been examined, with research showing that during booing, the visitor's team performance was worse than the home team's (Greer, 1983). However, there can be a negative impact as well, as shown by Thirer and Rampey (1979), in which antisocial behaviors by the crowd, defined as swearing and throwing objects among other things, affect the home team by causing it to commit more rule infractions.

While there has been research on home-court advantage, albeit with mixed results, it is also important to consider whether the fans present perceive they impact the game, as that can affect attendance and engagement. Within this context, this study explored the following question:

Research Question 3: To what extent do members of a collegiate men's basketball fan group perceive that they impact the outcome of the game?

\section{Sense of Community}

Another key area for study in any sports group is sense of community (Chalip, 2006), an idea first defined by Sarason (1974) as "perception of similarity to others, an acknowledged interdependence with others, and a willingness to maintain this interdependence" (p. 157). McMillan and Chavis (1986) operationalized this idea using four factors: needs fulfillment, membership, influence, and emotional connection. Warner and Dixon $(2011,2013)$ and Warner, Dixon, and Chalip (2012) have applied the sense of community construct to college sport participants, including both varsity and club athletes. Their findings included identifying new factors such as administrative consideration, leadership opportunities, equity in administrative decisions, competition, and social spaces. Holt (1995) used the idea of sense of community in examining how it develops in fans of a professional sports team, with findings indicating that sense of community must be promoted and does not occur on its own. Swyers (2005) and Lyons and Dionigi (2007) both point to a few key components of creating sense of community in sport such as shared spaces, camaraderie, and shared sport interest.

Research on brand communities is also relevant here as it shares some similarity to the idea of sense of community. Brand communities are defined by three markers: shared consciousness, rituals and traditions, and moral responsibility, and have the added element of being inherently commercial. Application of this idea has been supported in a variety of sport contexts. For example, Heere et al.(2011) studied students at three major Florida universities, finding that their team identity was affected by university, city, and state identities, indicating that brand community identification does not exist on its own, but can be impacted be different identities. Research on how brand communities are developed in sport has also been undertaken (Grant, Heere, \& Dickson, 2011; Katz \& Heere, 2013). Collectively, findings indicate that, much like sense of community, brand communities must also be fostered and developed within marketing strategies. Further, the communities themselves are often developed as a network, so for successful brand communities to exist, both "top down" and grass roots efforts are beneficial. 
Research on college sports fans has indicated the importance of fanship for college students in a variety of ways. For example, college students have reported a positive correlation between team identification and satisfaction with the university, sense of community on campus, social status, and social connections (Clopton, 2008; End, Kretschmar, \& Dietz-Uhler, 2004; Wann \& Robinson III, 2002; Wann, Waddill, Polk, \& Weaver, 2011). Further, integrating into the university is a key task for many incoming students, and joining clubs and groups is a primary way that many students attempt to integrate (Astin, 1993; Terenzini \& Pascarella, 1977; Tinto, 1987). Integration into the university has been linked with many positive outcomes such as positive perception of the university (Wann \& Robinson III, 2002), increased academic success (Schurr, Wittig, Ruble, \& Henriksen, 1993) and sense of community (Clopton, 2008). Following these lines, Warner et al. (2011) undertook a study within the unique circumstance of a university adding a football team, and how that might impact sense of community on campus. The authors found that sense of community was enhanced, but only for those students who attended the football games. In addition, it was found that sense of community had a positive impact on satisfaction with the university, retention, and current and future support of athletics, indicating varsity athletics are important to the university, but seemingly only for the students who are engaged with them.

Due to the importance of group identification (Tajfel \& Turner, 1986; Tajfel, 1981), it is important to explore the experiences of sport fan group participants. While there is research on fanship of college students, sense of community in college, and on sense of community in sports fans, this study attempts to fill a gap in the literature by exploring sense of community in sport fan groups by asking:

Research Question 4: Does participation in a student men's basketball fan
group affect sense of community on campus for the participants? Method

The researchers used an exploratory qualitative approach to explore experiences of a collegiate men's basketball fan group. The researchers chose this method to evaluate the shared experience of participating in an intercollegiate men's basketball fan group since there is limited literature on the stated research questions, and thus, exploratory, qualitative methodology was most appropriate (Creswell, 2013). To provide for richer data, and to provide data triangulation, the researchers felt both participant observation and interviews would be beneficial.

Orange Krush was chosen as the focal point for this study for several reasons. First, Orange Krush is nationally recognized as one of the best collegiate men's basketball cheering sections. It was voted the second best student section in the nation by SI.com in 2006 ("Best Student Section," 2006). The State Farm Center, formerly called the Assembly Hall, the home arena for men's and women's basketball, is often mentioned by visiting teams and broadcasters as a difficult place for visiting teams to play. This "home-court advantage" is mostly attributed by visitors and broadcasters alike to the loud, organized, and brightly colored Orange Krush student cheering section. As ESPN men's college basketball analyst Jay Bilas put it, "In the years I've been coming to the Assembly Hall, there's not been a fan base that's impressed me more than the Orange Krush" (Munson, 2010). 
Second, Orange Krush is one of the oldest student men's basketball fan groups in the nation, starting with just four members in 1975 ("About Orange Krush," 2013). Orange Krush is a large group, recently including anywhere between 600-2000 students, with its size generally fluctuating based on the recent success of the Illinois basketball team. Members initially had to take an Illini quiz to join; but currently, they are required to raise money for a variety of charities to join. The requirement to raise money to participate is a final reason this group is unique and appropriate for this research project. The Orange Krush Foundation, started in 1998, has currently donated over \$2 million to local and national charities ("About Orange Krush," 2013). Members are assigned different levels in the organization based on the amount of money they raise for charity. "Varsity" members must raise pledges totaling at least $\$ 1.50$ per three-point shot made. "All-Americans" must raise at least $\$ 3.00$. Finally, first year students are eligible for "Scout" status in which they are only required to raise pledges of at least $\$ 1.00$. Students line up for seats based on the level they are assigned to. Within each level, seats are first-come-first-served, resulting in students arriving to games hours early.

\section{Participants}

Interviewees were selected through convenience and snowball sampling, which allowed the participants to identify other cases of interest to provide for rich data (Creswell, 2013). A total of eleven Krush members were interviewed, as shown in Table 1. The initial interviewees were approached by the first author due to their extensive involvement in Krush, as suggested by leaders of the group. These interviewees also suggested other possible participants, who were contacted via e-mail by the first author. In addition, during the pregame "line up" for seats, the first author approached members randomly who were waiting in line to see if they would be willing to give an interview at a later date. Those students who were willing provided e-mail addresses so that the first author could contact them to arrange for an interview.

All interviewees were from the state of Illinois and white. Six were seniors, two juniors, two sophomores, and one was a freshman. Seven were male, and four female. While demographic information was not provided to the researchers by the group, visual observation of the group indicates that a majority of members are white and male, which is reflected in the sample. To protect the anonymity of the students, pseudonyms are used and their academic majors are generalized.

\section{Procedures}

The first author attended two home men's basketball games held at the State Farm Center in February and March of 2013 to conduct direct observations, late in the season for intercollegiate men's basketball. Both games were against Big Ten Conference opponents. The Illini won both games, one of which was a lopsided win, the other, competitive. The first author asked for and received permission from Orange Krush student leaders to sit in the Orange Krush section and participated in all cheers, chants, and rituals. Orange Krush seating is designated on a first-come, first-served basis within the three previously described Orange 
Table 1 Study Participants (pseudonyms used and majors generalized)

\begin{tabular}{lcllll}
\hline Name & $\begin{array}{c}\text { Years in } \\
\text { Krush }\end{array}$ & $\begin{array}{l}\text { Year in } \\
\text { school }\end{array}$ & Race & Gender & Major \\
\hline Mike & 3 & Junior & White & Male & Business \\
Jeremy & 3 & Senior & White & Male & Science \\
Peter & 2 & Sophomore & White & Male & Agriculture \\
Liam & 4 & Senior & White & Male & Science \\
Kate & 4 & Senior & White & Female & Humanities \\
Kevin & 2 & Sophomore & White & Male & Social Sciences \\
Kayla & 4 & Senior & White & Female & Science \\
Ashley & 4 & Senior & White & Female & Engineering \\
Brandon & 3 & Junior & White & Male & Science \\
Blake & 1 & Freshman & White & Male & Undecided \\
Heather & 4 & Senior & White & Female & Science \\
\hline
\end{tabular}

Krush levels. Most members sit on the floor on one end of the playing court, but depending on membership levels, overflow seating is available in the top section of the State Farm Center. Many members arrive several hours early to ensure the exciting atmosphere provided by the floor seating. The first author was able to sit in the floor seating for both games, choosing to sit in the back of the section to have the best vantage point for observation of the group members, and to limit any possible impact on the participants by the researcher's presence. As a former member of Orange Krush, and attendee of games as a fan, the first author had basic knowledge of many of the in-game activities of Orange Krush, and thus felt comfortable that the researcher's presence would not be distracting to the members. Short jottings were taken during the game and full field notes were written shortly after each game.

In addition, semistructured interviews were conducted with Orange Krush members to explore their perceptions of the fan group experience. The interview topics were drawn from observations at the games and previous research regarding motivations and benefits of sport consumption (End et al., 2004; Wann \& Robinson III, 2002; Wann et al., 2011), rituals (Drenten et al., 2009; Eastman \& Riggs, 1994), and sense of community (McMillan \& Chavis, 1986; Warner \& Dixon, 2011, 2013). Sample questions included "What are the meanings of the pre- and in-game rituals?", "What do you enjoy about being in Orange Krush?", and "Do you think you have an impact on the outcome of the game?" The interviews were semistructured to allow participants to offer their own perspectives and observations, but also to ensure a certain set of questions was answered for all participants (Creswell, 2013). The interviews lasted 30-50 minutes each and all participants agreed to audio recording. Interviews, conducted by the first author, were held at the student union, a central and public campus location convenient for participants. 


\section{Data Analysis}

The field notes were coded and analyzed first, to help the authors develop questions for the interviews. Field notes were typed and interviews transcribed verbatim, and both were coded using NVIVO 10 qualitative data analysis software. A priori themes were chosen from the existing literature (Cialdini et al., 1976; Clopton, 2008; Wann \& Robinson III, 2002; Wann, 1995; Warner \& Dixon, 2011, 2013) and provided categories into which the data were coded (Miles \& Huberman, 1994). These broad categories are related to the research questions. Next, open coding was used within each category/theme to analyze each transcript, with these codes grouped together into the themes (Creswell, 2013; Lincoln \& Guba, 1985). For example, some of the open codes that were used were "dressing up" and "pregame rituals." These codes were then combined together into the ritual theme. Last, the first author recoded using focused coding to highlight examples of the chosen themes (Emerson, Fretz, \& Shaw, 2011).

To enhance credibility, the authors used data triangulation, as evidenced by the use of multiple sources and two different data collection techniques. In addition, the researchers used the peer debriefing technique to further establish credibility and dependability (Lincoln \& Guba, 1985). More specifically, the second author was not involved in data collection, but served as an auditor to review analyses and interpretation, thus providing valuable peer feedback.

\section{Findings}

The purpose of this study was to explore experiences of a collegiate men's basketball fan group, particularly benefits related to participation, fan group rituals, perception of game impact, and sense of community on campus. Findings showed that students perceive many benefits to participating in the fan group, including Insider Access. In addition, the research showed that the students participated extensively in rituals and those rituals were important to the cohesiveness of the group. The students also indicated a perception that they had an impact on the game outcome, and felt that the group had a strong sense of community.

\section{Insider Access}

To address research question one, students were asked about the benefits of being in Orange Krush. Group members answered this in a variety of ways, including things such as free pizza, free T-shirts, and promotional items such as foam fingers. The participants also reflected previous literature on sport fan motivation (Funk et al., 2004; Milne \& McDonald, 1999; Trail \& James, 2001; Wann, 1995), such as escape and entertainment. For example, Mike reflected, "I enjoy the chants, [to] just jump around, not have a care in the world. Watch the best basketball in the country from the best seat in the house." Liam agreed, adding "it's a ton of fun because you get to go with a bunch of crazy people that are just like you."

However, the most common answer, one not previously found in the literature and thus deserving of focus here, was a reference to what the researchers have termed Insider Access, which refers to the intangible benefits the students receive due to their membership in Orange Krush. Many interviewees expressed an appreciation 
for seeing the "backstage" view of Illinois basketball. They enjoyed getting to the arena early, before other fans were allowed in and seeing the preparation that the players, coaches, media, and athletic department staff undertook before each game. As Peter said, "It's almost like you're on the bench, part of the game. Honestly, you couldn't be any more part of the game without actually playing in it." Peter continued by stating:

You get kind of a behind the scenes look at Illini basketball you don't see anywhere else. On game days you're in there an hour before tipoff, so you're getting to see the shoot around and you're getting to listen in on some of that stuff. You're right on top of the action that most folks are removed from.

Mike added:

The coolest benefit is the opportunity to be down on the court before it's open to the public. I wore the orange suit last year and got to shoot around with the players. There's only a few people in there, you can walk across the court and do whatever you want.

In addition, the fact that Orange Krush members sit so close to the floor adds to the idea of Insider Access. Many interviewees expressed enjoyment at hearing the players and referees talking to each other, and feeling that they understood the connection between the two groups. The relationship between referees and players can often be adversarial with disagreements over referee decisions; however, sitting closer to the floor often enables fans to see that in many cases, the referees and players are able to discuss the calls and rules without the discussion turning into an argument-something that is not always clear on television or from "the nosebleed seats."

Another Insider Access point was the desire for a connection to the players and coaches. Many interviewees expressed pleasure at the shows of appreciation the coaches and players give to Orange Krush members. Liam commented: "You're so close and personal and you feel like you know the players." Jeremy agreed, stating "especially with [head coach] coming to shake everyone's hand after the game, it really makes you feel part of the experience of Illini basketball. You're not just a fan any more, and you feel part of it."

In addition, Mike shared:

Getting to shake the coach's hand is pretty cool. It's something a lot of people talk about

... I like to see it, that he cares, that he appreciates what we're doing. Even after losses when it's pretty easy to duck back to the locker room, he takes the time to come over and thank everyone for coming.

Observation of two Illini basketball games by the first author confirmed the opportunity for Orange Krush members to gain Insider Access. The seats Orange Krush members sit in are directly behind the basket next to the opposing team's bench, where they can see and hear everything taking place on the court. In addition, the head coach coming to shake hands with Orange Krush members did seem to be genuine appreciation of Orange Krush's contributions to the game and appreciated 
by Orange Krush members. The players did not seem to interact directly with Orange Krush members, either before or after the game, which was reflected in the comments by Orange Krush members. Members discussed enjoyment of the connection with both players and coaches, but emphasized interaction with the coach more than players.

\section{Importance of Rituals}

Research question two sought to explore the extent, importance, and meaning of sport fan rituals in the student fan group. Numerous rituals were observed by the first author before and during the game, including stretching, cheers, chants, motions, movements, and signs. Based on observation, nearly all members took part in all the rituals throughout the event. The members were very active from about 10 minutes before tipoff to the end of the game. In addition, during interviews, the participants shared about activities they take part in as a group in an attempt to prepare for or impact the game. It was clear through both observation and interviews that Orange Krush members are heavily active in creating and maintaining rituals.

Pregame Rituals. Many of the rituals take place before the game, including pregame stretching by Orange Krush members. For example, Kate reflected:

It's our joke that our team is warming up and we're warming up too. But it also serves to get everyone pumped up about it. We're about to do something big again, so let's get ourselves ready. It's kind of a way to snap everyone into focus. Let's start thinking about how we're going to be a unified group in 10 minutes. We're going to get our heads in the game, and have fun doing it.

Peter echoed Kate's comments:

When you're stretching, it's like you're going into battle. You're going into a game. We're getting loosened up, we're getting ready to go, we're serious about this. We're trying to show the other team that we're here, we mean business, this is our house, and we're going to be coming out strong against you guys.

Brandon had a different take on the rituals, saying "I think it helps me put on the character of being that rowdy crazy fan maybe more so than just wearing a T-shirt and a ball cap. I can kind of take on a different personality." These quotes indicate how serious Orange Krush members take their responsibility toward helping the Illini to victory. The stretching serves to get the Orange Krush members physically and mentally prepared to participate in the sporting event. It was clear during observation that the Orange Krush members were not merely passive spectators at Illini basketball games; they were taking part in the action. The pregame rituals also were important in building sense of community within the group. As the members indicated, they stretch as one, to get ready to cheer as one. Another ritual observed by the primary researcher that takes place before the game occurs during the opposing team introductions. Orange Krush members hold up newspapers in front of their faces and ignore the opposing team, which serves to show that the opposing team is not worthy of Orange Krush's attention, and that they are no competition for the Illini. As Kevin reflected, "It's a sign of disrespect in a 
way. But I think through that disrespect it kind of brings Krush together, a uniform thing because everybody does it."

Dressing Up. Many Orange Krush members were also observed wearing a special outfit for games. All Orange Krush members receive an orange T-shirt as part of their membership, and they are to wear it during all games. However, some members take it a step further. One interviewee, Liam, was observed as dressed up as a cow for all games, stating, "I had two matching cow suits, so it just kind of evolved from there. People looked at us like we were insane when we first showed up wearing them, but then it turned into kind of a big thing." The first author observed Mike wearing Zubaz pants, which have an orange and blue zebra print. For big games, he purchased an orange suit, reflecting: "The day I put the suit on, I'd been looking forward to putting that on for a couple days. It definitely adds something." Jeremy wore the same outfit to games all three years he was in Orange Krush; replica Illini uniform, orange knee socks, and orange shoes. He explained: "I like to be orange from head to toe. I think it helps me get into the game a little bit more. [It] helps me prepare mentally. My mind has been conditioned that I'm wearing this outfit, I need to get excited, get ready to start yelling and screaming." Kate, who painted her face for every game, explained that "I do a different face paint design every game. I spend more time on face paint than makeup and I'm a little proud of that." Several Orange Krush members were observed wearing face paint with a variety of designs.

All interviewees expressed the importance of rituals in getting ready for the game. They considered their preparation similar to the way athletes prepare for their games. They talked about going into battle, preparing to fight, preparing mentally, and trying to intimidate the other team. The interviewees articulated that both individual and group rituals seem to enhance group affiliation and team identification as well. Postgame rituals were not mentioned often by interviewees. It seems that with the long time commitment before the games to get in line for seats, many students went home soon after games, or engaged in postgame activities that were not essential in ritual building.

\section{Perception of Game Impact}

Research question three explored the extent to which group members felt they impacted the outcome of the game. Orange Krush takes its mission of creating a difficult environment for their opponents very seriously with a variety of techniques and rituals designed to both energize the home team and distract the opposing team members, including vocal cheers, arm motions, and large signs. The students seemed to divide the cheering rituals into two categories: positively toward the home team and negatively toward its opponents, both of which they felt were impactful in the outcome of the game.

Positive Cheering. When asked, every interviewee indicated that he or she believes that Orange Krush does have an impact on the outcome of the game. The participants indicated that a ritual of loud positive cheering was most impactful in giving the home team energy to be successful. Mike stated: "I think certain games we can certainly help . . . it's extremely difficult to quantify what that impact is worth . . . 2-3 points, I don't know." Kayla agreed, stating: 
I think if it were quieter it would be harder for the team to build up the energy in the arena. I think having us there, knowing we're there no matter if they're going to win or lose is a big thing.

Kate also emphasized the impact the group can have:

I do firmly believe the student section can play a huge role in pumping up the team. You look at away games at the surprise road trips we go on, you can see [the players] getting amped up when we're there. With the [home game when Illini beat \#1 ranked team], I think we were a huge part of that. If you can keep positive energy going for them, even if it's not going well, there's no way they can [ignore that].

Peter added:

If you can get one fan to go nuts, it starts to spread to other fans, and you can really make more of an impact when you're actually in the environment. If we're not making a difference as Orange Krush, we're not doing our job.

Overall, Orange Krush members seemed to police themselves on appropriate forms of cheering. As Mike reflected, "it's more of an unwritten rule. . . . When you hear a student being overly negative ... quite a few people will say something. What are you contributing?" Jeremy added that "we are University of Illinois fans. Part of being a fan is rooting the team on through thick and thin. There's no positive to booing a team when they're down."

Negative Cheering. Several times during interviews, students mentioned the importance of being a "first class student section" and being better than the average student section. This seems to be evidenced by the emphasis on positive cheering toward the team. However, interestingly, the students' comments during interviews emphasized their potential effect on opponents as more impactful. As Peter reflected, "I think our impact is made more in getting in the heads of opposing players instead of encouraging our own." The primary way the participants felt they could be impactful toward the opposing teams was through loud ritual cheering or distraction through group activity. Jeremy explained:

I think in Krush, a lot of what we do is build momentum, especially on the defensive side, the louder you are as a student section, the harder it is for the opponent to get in a rhythm and call out their plays.

Orange Krush members have developed different cheers and chants to direct toward opposing players when they are shooting free throws at the basket behind which Orange Krush sits. Orange Krush members also often research embarrassing facts or stories about opposing teams to design distracting chants about that player. They have even gone so far as to keep a spreadsheet of statistics of which cheers are most effective and try to use those rituals during the most significant moments of the game. Blake said:

I believe Orange Krush provided that extra edge that was disrupting the opponent during free throws, inbounding the balls. We're yelling at the opponents and get in their heads, so it provides a lot of advantage to our team. 
Kevin pointed out the importance of cheering as a group, stating, "I think a big uniform group is more intimidating . . can interfere more with the opponent than a bunch of individuals doing different things." Another form of distraction are the giant cutout heads of famous people in Illinois history, such as Abraham Lincoln and Lou Henson, longtime Illinois men's basketball coach. These signs serve as another ritual to distract the opponents, in the hopes of positively impacting the game in favor of Illinois. The giant heads are also an example of identity expression, since they are of people with connections to the state of Illinois. As Kate expressed, "this is Illinois. This is what we do."

At one point during a game, the primary researcher witnessed an Orange Krush member continually shouting profanities at a referee. A security guard warned the student, but when the student continued his actions, Orange Krush members took it upon themselves to scold the student, and make it clear his behavior was unacceptable, which ended the behavior. Another example was observed when Orange Krush members were chanting "2-1-9" toward an opposing player. The first author asked an Orange Krush member what that was referring to, and he explained that it was the blood alcohol content recorded during a recent arrest of that player. This seems to be a direct and personal insult to a player, which interviewees asserted they tried to avoid. However, it also seemed to be an extreme example. At each home game, group members receive a brief newsletter, with group announcements, game notes, and perhaps most interestingly, notes on the opposing team and its players. These notes can be personal, usually highlighting something that students can use to "get in the heads" of the opposing players, such as a recent headline involving a player. The example outlined here was the only example of a more negative cheer witnessed by the researcher, but the inclusion of notes like these in the newsletters indicates that this negative focus may not be uncommon.

\section{Sense of Community}

Acquiring a sense of community is a motivation that has been found for sports fans in much of the research (Funk et al., 2004; Hirt et al., 1992; Madrigal, 1995; Milne \& McDonald, 1999; Wann, 1995). Research question four asked whether group members experienced sense of community in the group and on campus. Members of Orange Krush interviewed for this project spoke about a sense of community as one of the best things that resulted from being part Orange Krush.

Integrating Into the University. When trying to meet new people around campus, knowing that you have something in common with that person can make it easier to feel comfortable talking to new people and establishing oneself on campus. As Kate expressed, "I got to make friends with people who came up to me to talk to me about my face paint. You realize what a diversity of people there are in Krush." Jeremy added: "It enhances your community, you see people on the Quad that you know just because you see them at games. I think it's introduced me to people I wouldn't have met, especially in terms of people in other majors." Heather went even further, stating, "I'd say it's probably my number one experience I've had at U of I. Especially the road trips are just so much fun. I just love it." In addition, Mike explained: 
I feel like it really epitomizes the experience because it brings together all the students. We're all cheering for the same team, all on the same side. You get a true sense of Illini pride, and that's really what it's all about. Whether you're close or not, you have the common denominator that really brings everyone together. It really does bring out that sense of community that we're all here together and this is our school. It can make something out of nothing, it can reinforce relationships you already have, but also create great relationships where they're not previously.

Kayla also expressed a similar feeling:

Coming in as a freshman, I didn't really have an identity on campus and that was the first thing I really got into and it really made me realize it's a great school for me and it really gave me a sense of community in the whole school in general.

Emotional Connection. Finding common ground is a key component of creating sense of community. Orange Krush members immediately know that they and their fellow members have a commonality: Illini basketball. As Kayla recalled, "We all want to watch it together, we're not just watching it alone, we can cheer together and have the same ups and downs throughout the game." Kevin agreed, adding:

Part of meeting somebody is small talk at first and you gotta have something in common, so if you're at the games, that's a good way to unite two people that don't know each other. It just shows me that there is a community to be had, even on a campus of 40,000 people, there is a community to be had.

The emotional connection that brings the student together through Illini basketball can be made even stronger during times of exuberance, as Mike explained: "At the end of the [home game at which Illinois beat \#1 ranked team] game, I was just hugging everyone. I was hugging my friends, I was hugging everyone in orange. Everyone in orange was my friend at that time, that's what it's like.

The level of emotional connection expressed by the participants also reflects previous research on social networks. As Katz and Heere (2013) found, distinct, smaller networks can be found within a larger fan group, often differentiated by their levels of involvement. In this case, some of the participants indicated that they shared a greater emotional connection with other students who expressed similar levels of involvement. As Brandon stated "certainly the Midwest winters weed out some folks. But there's a part of me that says, if you're not that dedicated, to stand out in -10 for two hours ..." Kate also noted a difference in levels of involvement in the group:

Everyone has different levels of involvement. I love everyone being in Krush, I don't care if you just started following this year or if you've been following all your life. There are people that know way more than I do in Krush, and I consider myself pretty knowledgeable, but there are definitely different levels of involvement.

Peter also commented on the different networks that form within the group, by saying "I mean because we have a large group, 850 members this year, there's 
probably a core of 50 or 100 members that I'd consider friends and are coming to everything and part of my community."

Although all interviewees expressed their appreciation of meeting other students on campus through Orange Krush, this was not specifically witnessed during the direct observation completed by the first author. Sense of community is an intangible construct which is difficult to quantify, however, it appeared that students seemed to spend time in small groups of 2-3 people that arrived at the game together, indicating that they already knew each other. Even during the games, it appeared that it was only during moments of extreme exuberance that students interacted with students outside their smaller group. This supports previous research by Katz and Heere (2013) in which smaller networks exist within a larger community. The two games attended were at the end of the basketball season, so it is possible that more community building took place at the beginning of the season. It is also possible that community building occurs at other places on campus as students recognize other Orange Krush members outside of games or Orange Krush events and feel comfortable approaching each other. Nevertheless, data do suggest that Orange Krush members develop a sense of community through affiliation with the student group.

\section{Discussion}

The purpose of this study was to explore the experiences of participants in a collegiate men's basketball fan group. Findings showed that one of the most important benefits was Insider Access. In addition, the study showed that rituals are very important to the group and contribute to a perceived impact on the game. Finally, the participants also indicated that their sense of community on campus was enhanced by participation in the group.

Research question one explored the benefits of participation in Orange Krush. In addition to reporting benefits that have been found previously, such as escape, entertainment, and social interaction (Funk et al., 2009; Milne \& McDonald, 1999; Trail \& James, 2001; Wann, 1995), participants also expressed a benefit not discussed in the sport literature: Insider Access. It seemed clear that the extra knowledge gained from watching the games from the floor seating and enjoying the backstage view of Illinois basketball was quite valuable to these students. Behind the scenes access has been shown to be important to fans of other leisure activities, such as television viewing (Andrejevic, 2008; Baym, 1999). Orange Krush members feel they know the players and coaches because they interact with them on a personal level, which can increase their fan identification because they feel a more personal tie to the program (Lock et al., 2012). It is especially interesting to note the relationship between college athletes and college student fan sections. These two groups are peers and may share classes or even dormitories with each other. However, this did not seem to change the feeling of idolization of the players and the program as a whole. It was still deemed special and desirable to have a connection with the players, even though the students and players could interact in many other scenarios on campus. Interestingly, the members of the group said they felt like they knew the players, but when pressed on this, they acknowledged that this was a superficial connection, and the students' involvement in Orange Krush did not lead to socializing between the students and players off the court. 
Feeling like an Insider, or that they are allowed to be part of things that the average fan is not, seems to result in Krush members feeling special and part of the Illinois basketball program. The desire for Insider Access can also be reflected in other sport fan behaviors. For example, many people enjoy taking a tour of their favorite team's stadium. The tour often allows fans to see the locker room, go down onto the playing field, or see another area of the stadium they have not seen before. This insider knowledge helps fans feel closer to their teams since they are allowed "backstage" access (Gammon \& Fear, 2005). Even something as simple as a handshake from the head coach seems to make a big impact on these students. While this was not articulated by interviewees, it is likely that this knowledge from sitting so close to the floor helps the fan feel more authentic. This authenticity of fandom is an important concept for many fans (Sutton, McDonald, Milne, \& Cimperman, 1997). As previously mentioned, group affiliation is an important benefit for many fans; they love to sit with other fans and talk about their teams, both the positive aspects and the negative. The knowledge gained from sitting so close to the floor is beneficial in helping these fans have information that their friends do not, so they may believe they are a better, more authentic, fan. Thus, the current project has contributed to the extant literature by finding an important benefit for participation in a collegiate men's basketball fan group is Insider Access.

The purpose of research question two was to study the extent and importance of rituals to the group. Given the prevalence of lucky jerseys, cheers, chants, hand motions, songs, and other rituals, it is an area ripe for additional research. Pregame rituals of Orange Krush members were found to be an important avenue for mental preparation for participation in the sporting event and for increasing involvement in the event (Drenten et al., 2009). Participants treated their pregame rituals in much the same way as the athletes (e.g., having a routine, wearing a special outfit, stretching to prepare the body physically and mentally). The participants spoke of the pregame ritual as though they were preparing for battle, indicating how seriously they took their duties in creating game impact.

This study also showed that rituals were an important way that sports fans create sense of community. During the game, doing the same cheers and singing the same songs together creates a connection for fans, both with the team, and with each other. Participation in rituals also signifies membership in the group, and it creates an in-group and out-group mentality which is also helpful in building a sport team identity (Eastman \& Riggs, 1994). Many of the rituals also reflected the specific identity of Illinois, which supports previous research on brand communities (Heere et al., 2011). The current study showed that sport fan groups are very active in creating and maintaining rituals, and extended the literature on fan rituals by connecting the importance of rituals to perception of game impact.

Research question three sought to extend the literature on rituals and examine the students' perceptions of whether their actions impacted the game. The findings indicated that the students do perceive that they positively impact the game in favor of the Illini. Home court advantage is a common phenomenon, as indicated by the fact that a team's win/loss record at home is often better than the record on the road. However, it is very difficult to define what accounts for this. Certainly factors such as a familiar environment, not having to travel, having family and friends near, and comfort with the playing field itself are all advantages for a home team (Carron, Loughhead, \& Bray, 2005; Courneya \& Carron, 1992). The force of 
a home-friendly crowd, however, cannot be overlooked. Something as simple as noise preventing a team from executing its plays can have an impact on the game, and thus, the impact of a home crowd on the mental state of opposing players is an important factor affecting game outcomes. Recent research has confirmed a collegiate fan group's impact on performance on the court by measuring free throw percentage made at home and on the road (Wolfers, 2015). The researchers found that the fan group at Arizona State University "appears to give Arizona State an additional one- to two-point advantage per home game, beyond the normal home court advantage" (Wolfers, 2015, para. 4) through their actions during opposing team's free throws. Regardless of the actual game impact, however, the fact that Krush students believe there is an impact is important to note. The importance of rituals seemed to be enhanced by the idea that the students were impacting the game, and were acting together with a common purpose.

Research question four examined whether participation in the group affected sense of community on campus for the participants. The interviewees indicated that they did perceive an enhanced sense of community on campus due to their membership in Orange Krush. Sense of community is similar to the idea of group affiliation, which has been previously found as a primary motivation in the sport fan literature (Milne \& McDonald, 1999; Trail \& James, 2001; Wann, 1995). Sports fans seem to gain much more enjoyment of sport by being able to share it with others. Orange Krush members expressed enjoyment of being able to hang out with their friends, make new friends, or even make connections with family members. Previous research has shown a relationship between college students' identification with the school's athletic teams and a sense of community on campus (Clopton, 2008). The present study extends this work into sport fan groups, importantly showing that participants' sense of community on campus was reportedly enhanced due to participation in Orange Krush. It is especially important to note that participation in the group does not only result in sense of community within the group, but within campus as well. Participants appreciated being able to go to their classes and other places on campus and find others with whom they instantly have a connection. Especially on large college campuses, establishing a connection with others can be difficult for students, so finding common ground is helpful for integrating into the university, which has many positive outcomes (Astin, 1993; Terenzini \& Pascarella, 1977; Tinto, 1987). Students are exposed to students in other majors they may not have ever met otherwise, and students are also able to build relationships they may have already had by connecting through sport. Thus, the current study extends the literature on sense of community by showing how it can be enhanced through participation in a collegiate sport fan group, not just by being a fan, a previously unexplored area in the sense of community research.

\section{Practical Implications}

As sport is a critical part of many American colleges and universities, it is important to continue exploring the experiences of sport consumers in various phases of consumption. This study demonstrates that an important, previously unexplored benefit associated with participation in a collegiate men's basketball fan group is Insider Access. Sport managers should continue to identify creative ways to provide opportunities for fans to interact with coaches and players, as well as provide 
"behind the scenes" information for fans. For example, sport managers should offer and encourage participation in tours of home facilities, arrange meet and greet events, and take advantage of social media to show pictures from the locker room, team bus, or practices. In addition, managers should encourage active fan participation in games and emphasize the important role fans play in potentially impacting the outcome of the game. This study also illuminates the importance of ritual in providing a common purpose for a student fan group, which in turn enhances a sense of community within the group. While many rituals are started at the "grass roots" level, managers can look for opportunities to encourage ritual building among fan group members and provide support for such rituals to increase identification and sense of community, and enhance perceived impact on the game. Finally, university leaders can use the information from this study to continue to encourage participation in sport fan student groups to enhance sense of community on campus.

\section{Limitations and Future Directions}

There are several limitations that should be considered when evaluating the results of this study. First, the small sample size of interviewees makes it difficult to extend the results beyond that of this collegiate fan group. Additional research should be completed with a larger sample from student fan groups, including fan groups from a wide variety of sports. Second, a more diverse sample would also be beneficial in exploring possible differences for underrepresented groups. In addition, this study was undertaken at only one institution, so further research should be conducted at a variety of colleges and universities and from different NCAA divisions and levels of competition (Football Bowl Subdivision, Football Championship Subdivision, Division II, Division III). All of these recommendations would be important for exploring a wider variety of student groups and situations to enhance generalizability. Further, the first author attended just two games, so a more longitudinal approach may be of value in expanding the results. In addition, the fact that both games attended by the first author were wins for the home team could have impacted the results, particularly in relation to perception of game impact. Since the data are represented by personal observations and interpretations of interviews, and since the first author is a former member of the group, researcher bias may have been introduced into the study. The authors minimized this concern by having the first author conduct data collection and analysis, while the second author served as a peer debriefer. More specifically, the second author was consulted regarding codes, reviewed theoretical memos, helped analyze main themes, and provided feedback regarding interpretation of themes (Lincoln \& Guba, 1985).

Future directions of this research could include many avenues. First, comparison of fan groups across sports and leagues would be beneficial. For example, comparing student fan groups with alumni groups of the same institution would be helpful in building on the themes presented here. In addition, comparing university fan groups with fan groups for professional teams would also be enlightening. A comparison of fan groups on campus with nonfan groups regarding sense of community would add to the literature in that area. Finally, since perception of game impact as it is related to rituals is a new finding, more research should be conducted in a variety of settings to explore this concept further. 


\section{Conclusion}

This study explored the experiences of collegiate men's basketball fan groups, drawing forth themes on benefits of participation related to Insider Access, perception of game impact, sport rituals, and sense of community. The study showed that a key benefit of collegiate men's basketball fan groups is the perception of being an Insider. In addition, the members of the fan group believe they have an impact on the game and that sport rituals are an important part of the game experience. This study also found that participation in a collegiate men's basketball fan group builds sense of community within the group and on campus. Information from this study is useful to sport managers because it is important for them to understand the experiences of their fans to ensure continued loyalty from those groups. Sport managers can also use this study to build programs and events to enhance the fan experience, particularly in creating Insider Access and encouraging perception of game impact. In addition, this research illuminates the meaning of the fan group to the students participating in it, and its role in the students' collegiate experience.

\section{References}

About Orange Krush. (2013). Retrieved from http://illinipride.com/orange-krush/42-aboutthe-orange-krush-foundation/

Andrejevic, M. (2008). Watching television without pity: The productivity of online fans. Television \& New Media, 9(1), 24-46. doi:10.1177/1527476407307241

Astin, A.W. (1993). What matters in college?: Four critical years revisited. San Francisco, CA: Jossey-Bass.

Baym, N.J. (1999). Tune in, log on: Soaps, fandom, and online community. Thousand Oaks, CA: Sage.

Best Student Section. (2006). Retrieved from http://sportsillustrated.cnn.com/2006/sioncampus/02/20/spring.break2/1.html

Branscombe, N.R., \& Wann, D.L. (1991). The positive social and self concept consequences of sports team identification. Journal of Sport and Social Issues, 15(2), 115-127. doi:10.1177/019372359101500202

Brown, M. (2015). March Madness Continues To See Record-Setting TV Ratings. Forbes. Retrieved from http://www.forbes.com/sites/maurybrown/2015/03/22/march-madnesscontinues-to-see-record-setting-tv-ratings/print/

Carron, A.V., Loughhead, T.M., \& Bray, S.R. (2005). The home advantage in sport competitions: Courneya and Carron's (1992) conceptual framework a decade later. Journal of Sports Sciences, 23(4), 395-407. PubMed doi:10.1080/02640410400021542

Chalip, L. (2006). Toward a distinctive sport management discipline. Journal of Sport Management, 20(1), 1-21.

Chun, S., Gentry, J.W., \& McGinnis, L.P. (2005). Ritual aspects of sports consumption: How do sports fans become ritualized? Asia Pacific Advances in Consumer Research, 6, 331-336. Retrieved from http://search.ebscohost.com/login.aspx?direct=true \&db= bth\&AN=26767709\&site $=$ ehost-live

Cialdini, R. B., Borden, R. J., Thorne, A., Walker, M. R., Freeman, S., \& Sloan, L. R. (1976). Basking in reflected glory: Three (football) field studies. Journal of Personality and Social Psychology, 34(3), 366-375. Retrieved from http://dx.doi.org/10.1037/00223514.34.3.366

Clopton, A.W. (2008). College sports on campus: Uncovering the link between fan identification and sense of community. International Journal of Sport Management, 9(4), 
343-362 Retrieved from http://search.ebscohost.com/login.aspx?direct=true \&db=sph $\& \mathrm{AN}=35133352 \&$ site $=$ ehost-live.

Collins, R. (2004). Interaction Ritual Chains. Princeton, NJ: Princeton University Press. doi:10.1515/9781400851744

Cottingham, M.D. (2012). Interaction Ritual Theory and Sports Fans: Emotion, Symbols, and Solidarity. Sociology of Sport Journal, 29(2), 168-185.

Courneya, K.S., \& Carron, A.V. (1992). The home advantage in sport competitions: A literature review. Journal of Sport \& Exercise Psychology, 14(1), 13-27.

Creswell, J.W. (2013). Qualitative inquiry and research design (3rd ed.). Los Angeles, CA: Sage.

Donohue, J.J. (1993). The ritual dimension of karate-do. Journal of Ritual Studies, 7(1), $105-124$.

Dowie, J. (1982). Why Spain should win the world cup. New Scientist, 94(1309), 693-695.

Drenten, J., Peters, C.O., Leigh, T., \& Hollenbeck, C.R. (2009). Not Just a Party in the Parking Lot: An Exploratory Investigation of the Motives Underlying the Ritual Commitment of Football Tailgaters. Sport Marketing Quarterly, 18(2), 92-106.

Dubner, S.J. (2013). How money is march madness? Retrieved from http://freakonomics. com/2013/03/21/how-money-is-march-madness-a-new-marketplace-podcast/

Eastman, S.T., \& Riggs, K.E. (1994). Televised sports and ritual: fan experiences. Sociology of Sport Journal, 11(3), 249-274.

Emerson, R.M., Fretz, R.I., \& Shaw, L.L. (2011). Writing ethnographic fieldnotes (Vol. 2nd). Chicago: University of Chicago Press. doi:10.7208/chicago/9780226206868.001.0001

End, C.M., Kretschmar, J.M., \& Dietz-Uhler, B. (2004). College Students' Perceptions of Sports Fandom as a Social Status Determinant. International Sports Journal, 8(1), 114-123. Retrieved from http://search.ebscohost.com/login.aspx?direct=true \&db=ap h\&AN=11913232\&site=ehost-live

Funk, D.C., Filo, K., Beaton, A.A., \& Pritchard, M. (2009). Measuring the Motives of Sport Event Attendance: Bridging the Academic- Practitioner Divide to Understanding Behavior. Sport Marketing Quarterly, 18(3), 126-138. Retrieved from http://search. ebscohost.com/login.aspx?direct=true $\& \mathrm{db}=\mathrm{bth} \& \mathrm{AN}=44496294 \&$ site=ehost-live

Funk, D.C., Ridinger, L.L., \& Moorman, A.M. (2003). Understanding Consumer Support: Extending the Sport Interest Inventory (SII) to Examine Individual Differences among Women's Professional Sport Consumers. Sport Management Review, 6(1), 1-31. doi:10.1016/S1441-3523(03)70051-5

Funk, D.C., Ridinger, L.L., \& Moorman, A.M. (2004). Exploring Origins of Involvement: Understanding the Relationship Between Consumer Motives and Involvement with Professional Sport Teams. Leisure Sciences, 26(1), 35-61. doi:10.1080/01490400490272440

Gammon, S., \& Fear, V. (2005). Stadia tours and the power of backstage. Journal of Sport \& Tourism, 10(4), 243-252 Retrieved from http://search.ebscohost.com/login.aspx?dir ect $=$ true $\& d b=$ sph \&AN=21540199\&site=ehost-live. doi $: 10.1080 / 14775080600805457$

Gordon, K.O. (2013). Emotion and memory in nostalgia sport tourism: examining the attraction to postmodern ballparks through an interdisciplinary lens. Journal of Sport \& Tourism, 18(3), 217-239. doi:10.1080/14775085.2013.846228

Granskog, J.E. (1993). In Search of the Ultimate: Ritual Aspects of the Hawaiian Ironman Triathlon. Journal of Ritual Studies, 7(1), 3-25 Retrieved from http://search.ebscohost. com/login.aspx?direct=true \&db=rfh\&AN=ATLA0000864936\&site=ehost-live.

Grant, N., Heere, B., \& Dickson, G. (2011). New sport teams and the development of brand community. European Sport Management Quarterly, 11(1), 35-54. doi:10.1080/161 84742.2010 .537364

Greer, D.L. (1983). Spectator booing and the home advantage: A study of social influence in the basketball arena. Social Psychology Quarterly, 46(3), 252-261. doi:10.2307/3033796

Guttmann, A. (1978). From ritual to record: The nature of modern sports. New York: Columbia University Press. 
Heere, B., Walker, M., Yoshida, M., Ko, Y.J., Jordan, J.S., \& James, J.D. (2011). Brand community development through associated communities: Grounding community measurement within social identity theory. Journal of Marketing Theory and Practice, 19(4), 407-422. doi:10.2753/MTP1069-6679190404

Hirt, E.R., Zillmann, D., Erickson, G.A., \& Kennedy, C. (1992). Cost and benefits of allegiance: changes in fans' self-ascribed competencies after team victory versus defeat. Journal of Personality and Social Psychology, 63(5), 724-738. doi:10.1037/00223514.63.5.724

Holt, D.B. (1992). Examining the Descriptive Value of" Ritual" in Consumer Behavior: View From the Field. Advances in Consumer Research. Association for Consumer Research (U. S.), 19(1), 213-218.

Holt, D.B. (1995). How consumers consume: A typology of consumption practices. The Journal of Consumer Research, 22(1), 1-16. doi:10.1086/209431

James, J.D., Breezeel, G.S., \& Ross, S. (2001). A Two-Stage Study of the Reasons to Begin and Continue Tailgating. Sport Marketing Quarterly, 10(4), 212-223. Retrieved from http://search.ebscohost.com/login.aspx?direct=true \&db=bth\&AN=5846548\&site=e host-live

Katz, M.J., \& Heere, B. (2013). Leaders and followers: An exploration of the notion of scale-free networks within a new brand community. Journal of Sport Management, 27(4), 271-287 Retrieved from http://search.ebscohost.com/login.aspx?direct=true\& $\mathrm{db}=\mathrm{aph} \& \mathrm{AN}=89906995 \&$ site $=$ ehost-live.

Kim, Y.K., \& Trail, G.T. (2010). Constraints and Motivators: A New Model to Explain Sport Consumer Behavior. Journal of Sport Management, 24(2), 190-210 Retrieved from http://search.ebscohost.com/login.aspx?direct=true \&db=bth\&AN=48683500\& site=ehost-live.

Lincoln, Y.S., \& Guba, E.G. (1985). Naturalistic inquiry. Los Angeles, CA: Sage.

Lock, D., Taylor, T., Funk, D.C., \& Darcy, S. (2012). Exploring the development of team identification. Journal of Sport Management, 26(4), 283-294 Retrieved from http://search. ebscohost.com/login.aspx?direct=true $\& \mathrm{db}=\mathrm{aph} \& \mathrm{AN}=78382937 \&$ site=ehost-live.

Lyons, K., \& Dionigi, R.A. (2007). Transcending emotional community: A qualitative examination of older adults and masters' sports participation. Leisure Sciences, 29(4), 375-389. doi:10.1080/01490400701394881

Madrigal, R. (1995). Cognitive and affective determinants of fan satisfaction with sporting attendance. Journal of Leisure Research. http://doi.org/Article

McDonald, H., \& Karg, A.J. (2014). Managing co-creation in professional sports: The antecedents and consequences of ritualized spectator behavior. Sport Management Review, 17(3), 292-309. doi:10.1016/j.smr.2013.07.004

McMillan, D.W., \& Chavis, D.M. (1986). Sense of community: A definition and theory. Journal of Community Psychology, 14(1), 6-23. doi:10.1002/1520-6629(198601)14:1<6::AIDJCOP2290140103>3.0.CO;2-I

Melnick, M.J. (1993). Searching for Sociability in the Stands: A Theory of Sports Spectating. Journal of Sport Management, 7(1), 44-60 Retrieved from http://search.ebscohost. com/login.aspx?direct=true $\& \mathrm{db}=\mathrm{sph} \& \mathrm{AN}=16592597 \&$ site $=$ ehost-live.

Miles, M.B., \& Huberman, A.M. (1994). Qualitative data Analysis: An expanded sourcebook. Thousand Oaks, CA: SAGE Publications.

Milne, G.R., \& McDonald, M.A. (1999). Sport marketing: Managing the exchange process. Sudbury, MA: Jones and Bartlett Publishers.

Muniz, A.M., \& O'Guinn, T.C. (2001). Brand community. The Journal of Consumer Research, 27(4), 412-432. doi:10.1086/319618

Munson, K. (2010, February 8). College GameDay crew's thoughts on visit to Champaign. The Daily Illini.

Murrell, A.J., \& Dietz-Uhler, B. (1992). Fan Support of Sport Teams: The Effect of a Common Group Identify. Journal of Sport \& Exercise Psychology, 14, 28-39. 
NCAA. (2015). 2015 NCAA tournament has highest average viewership in 22 years. Retrieved from http://www.ncaa.com/news/ncaa/article/2015-04-07/2015-ncaatournament-has-highest-average-viewership-22-years

Pollard, R. (1986). Home advantage in soccer: A retrospective analysis. Journal of Sports Sciences, 4(3), 237-248. PubMed doi:10.1080/02640418608732122

Pope, D.G., \& Pope, J.C. (2014). Understanding college application decisions: Why college sports success matters. Journal of Sports Economics, 15(2), 107-131. doi:10.1177/1527002512445569

Rook, D.W. (1985). The ritual dimension of consumer behavior. The Journal of Consumer Research, 12(3), 251. doi:10.1086/208514

Sarason, S.B. (1974). The psychological sense of community: Prospects for a community psychology. San Francisco, CA: Jossey-Bass.

Scholes, J. (2005). The Bartman ball and sacrifice: Ambiguity in an American ritual. Journal of Religion \& Society, 7(7), 1-13.

Schurr, K.T., Wittig, A.F., Ruble, V.E., \& Henriksen, L.W. (1993). College graduation rates of student athletes and students attending college male basketball games: A case study. Journal of Sport Behavior, 16, 33-41.

Schwartz, B., \& Barsky, S.F. (1977). The home advantage. Social Forces, 55(3), 641-661. doi:10.1093/sf/55.3.641

Sutton, W.A., McDonald, M.A., Milne, G.R., \& Cimperman, J. (1997). Creating and fostering fan identification in professional sports. Sport Marketing Quarterly, 6(1), 15-22. Retrieved from http://search.ebscohost.com/login.aspx?direct=true \&db=sph\&AN=1 $6462662 \&$ site $=$ ehost-live

Swyers, H. (2005). Community America: Who owns Wrigley Field? The International Journal of the History of Sport, 22(6), 1086-1105 Retrieved from http://articles.sirc. $\mathrm{ca} /$ search.cfm?id=S-1000423. doi:10.1080/09523360500286783

Tajfel, H. (1981). Human groups and social categories: studies in social psychology. London: Cambridge University Press.

Tajfel, H., \& Turner, J.C. (1986). The social identity theory of inter-group behavior. In S. Worchel \& W.G. Austin (Eds.), Psychology of Intergroup Relations (pp. 276-293). New York, NY.

Terenzini, P.T., \& Pascarella, E.T. (1977). Voluntary freshman attrition and patterns of social and academic integration in a university: A test of a conceptual model. Research in Higher Education, 6(1), 25-43. doi:10.1007/BF00992014

Thirer, J., \& Rampey, M.S. (1979). Effects of abusive spectators' behavior on performance of home and visiting intercollegiate basketball teams. Perceptual and Motor Skills, 48(3c), 1047-1053. doi:10.2466/pms.1979.48.3c.1047

Tinto, V. (1987). Leaving college: Rethinking the causes and cures of student attrition. Chicago, IL: University of Chicago Press.

Trail, G.T., \& James, J.D. (2001). The Motivation Scale for Sport Consumption: Assessment of the scale's psychometric properties. Journal of Sport Behavior, 24(1), 108-127 Retrieved from http://articles.sirc.ca/search.cfm?id=S-671998.

Turner, J.C., Hogg, M.A., Oakes, P.J., Reicher, S.D., \& Wetherell, M.S. (1987). Rediscovering the Social Group: A self-categorization Theory. Cambridge, MA: Blackwell.

Wann, D.L. (1995). Preliminary validation of the Sport Fan Motivation Scale. Journal of Sport and Social Issues, 19(4), 377-396 abstract Retrieved from http://jss.sagepub. com/content/19/4/377. doi:10.1177/019372395019004004

Wann, D.L. (2006). Examining the potential causal relationship between sport team identification and psychological well-being. Journal of Sport Behavior, 29(1), 79-95 Retrieved from http://search.ebscohost.com/login.aspx?direct=true \&db=sph\&AN=1 $9824572 \&$ site $=$ ehost-live. 
Wann, D.L., \& Robinson, T.N., III. (2002). The relationship between sport team identification and integration into and perception of a university. International Sports Journal, 6(1), 36-44. Retrieved from http://articles.sirc.ca/search.cfm?id=S-801332

Wann, D.L., Waddill, P.J., Polk, J., \& Weaver, S. (2011). The Team Identification-Social Psychological Health Model: Sport fans gaining connections to others via sport team identification. Group Dynamics, 15(1), 75-89 Retrieved from http://search.ebscohost. com/login.aspx?direct=true $\& \mathrm{db}=$ sih $\& \mathrm{AN}=59334351 \&$ site=ehost-live. doi: $10.1037 /$ a0020780

Warner, S., \& Dixon, M.A. (2011). Understanding sense of community from the athlete's perspective. Journal of Sport Management, 25(3), 257-271.

Warner, S., \& Dixon, M.A. (2013). Sports and community on campus: Constructing a sports experience that matters. Journal of College Student Development, 54(3), 283-298. doi:10.1353/csd.2013.0044

Warner, S., Dixon, M.A., \& Chalip, L. (2012). The impact of formal versus informal sport: Mapping the differences in sense of community. Journal of Community Psychology, 40(8), 983-1003. doi:10.1002/jcop.21506

Warner, S., Shapiro, S.L., Dixon, M.A., Ridinger, L.L., \& Harrison, S.B. (2011). Football factor: Shaping community on campus. Journal of Issues in Intercollegiate Athletics, 4, 236-256.

Williams, J., \& Chinn, S.J. (2010). Meeting relationship-marketing goals through social media: a conceptual model for sport marketers. International Journal of Sport Communication, 3, 422-437.

Wolfers, J. (2015). How Arizona State reinvented free-throw distraction. New York Times. Retrieved from http://www.nytimes.com/2015/02/14/upshot/how-arizona-statereinvented-free-throw-distraction.html?_r=0\&abt=0002\&abg=1 